\title{
GOVERNMENTAL LIQUIDITIES MANAGEMENT 2008-2010
}

\author{
Andrei Laurentiu Dumitru, Ph.D. Student \\ University of Economic Studies, Bucharest, Romania, \\ andrei_laurentiu@yahoo.com \\ Vlad Cristina, Ph.D. Student \\ University of Economic Studies, Bucharest, Romania \\ cristina.vlad8@gmail.com \\ Professor Brezeanu Petre, Ph.D. \\ Faculty of Finance, Insurance, Banking and Stock Exchange, \\ University of Economic Studies, Bucharest, Romania, \\ brezeanupetre@yahoo.com
}

(Received April 2015; accepted June 2015)

\begin{abstract}
This article opens a suite dedicated to State Treasury financial structure optimization. It further develops our previous excursus on State Treasury mechanism, operation policies and practice, alignment to EU regulations, and the influence of fiscal pressure on the EU states economies.

This article concentrates on risk prevention and containment of the possible impact. It further describes the financing policy that has been adopted. The following section describes the effects of the applied policies and practice, as well as the accessed financial package.

We have included a lessons learned section, to outline what we strongly believe should achieved for enriching the data sets and processing automation - these being instrumental to ensure the accuracy and relevance of the decision process and actions.

We finally project the main theme of the future articles and to outline the need of competitive central administration partner for the national business community - which is tightly and ever tighter connected to its global counterparties.
\end{abstract}

Keywords: crisis, globalization, collections, payments, financial flows, financing, balance, technology, innovation, liquidity, competition, risks, stability and prudential policies

JEL Classification: H50, H63

\section{Risk Prevention and containment \\ Global Context}

The dynamics of globalization and integration of financial industry project the existence of a direct link between the persistent crisis on international markets and the way the financial sector evolved in the last two decades toward a complete liberalization and separation from real economy processes.

Financial innovation allowed risk distribution and its packaging in complex products, not permitting a thorough evaluation of their high risk of exposure to market fluctuations. The most notorious example is the financial products related 
Ipate, N., David K.G., Ipate, I., Bogdan, A.T., (2015)

The bioeconomy model in future sustainable development

with the high level risk mortgaging credits market based on a false prognosis for real estate prices growth.

The losses caused by the sub-prime crisis represent the symptom of a structural deficit in the regulations of financial markets and commercial practices, an early clue indicated by a series of warnings made by important personalities such as Alexander Lamfalussy ${ }^{1}$, the American economists Paul Volker and Paul Krugman and the American magnate Warren Buffet.

The accumulation of a huge fictitious capital on the financial markets had an important contribution to accentuating social inequities transformed by the increase of food and energy prices in humanitarian tragedies. Simultaneously, the financial markets adjustment as a result of speculative capital refolding creates a serious concern regarding economic growth which still affects the European Union and whose evolution is difficult to anticipate.

\section{Romania 2008 Context}

In the context of multiple shocks, the world economy presented a significant slowdown during 2008, from $5 \%$ in 2007 to $3 \%$ in 2008, estimating an only $2 \%$ global growth in 2009. The economic growth in the most developed seven countries (G7) slowed down to only $1 \%$ in 2008 whiles in 2009 the first economic contraction after 1982 was expected. According to this projection, world commerce evolution presented a significant deterioration, from $7 \%$ in 2007 and 5\% in 2008 to only $2 \%$ in 2009 , being exacerbated by global financial crisis effects and the difficulty of obtaining the necessary resources for financing ${ }^{2}$.

The Euro zone, USA, and Japan were already in recession, with a persisting risk that the situation will still worsen, offering impulses which emphasized: the continuous reduction of consumption and investments, generating a spiral of decline in demand, reduction of companies' budgets, innovation and employment.

The world economic projections marked an almost zero economic growth and registered the risk of an European economy contraction in 2009, estimating an increase with approx. 2.7 millions of the number of unemployed in the next two years.

The financial plan structure, in the context of estimates for internal and external financial markets evolutions in order to ensure the consolidated general budget deficit financing policy and the refinancing of the public debt, took also into account the harmonization of financial policies of the Ministry for Public Finance with the monetary policy of the National Bank of Romania, coupling the yields offered by State Treasury bonds with the monetary policy interest rate of the National Bank of Romania, taking into account the achievement of a symmetrical corridor between them - in order to avoid an anchoring of inflationary expectations, to sustainably achieve the disinflation goals in the medium term. 
In this context, Romania was at the end of an ascending slope of an 8-9 year economic cycle, characterized by ${ }^{3}$ :

$\checkmark$ The dynamics of the consolidated budget expenditures in economic classification indicate the strong acceleration in the growth rate for staff costs, materials, grants, capital expenditures and interest in the first 4 months of 2008 compared to the same period in previous years.

$\checkmark$ Staff costs rose by the highest rate in the last 4 previous years (48\% in $2008 / 2007$ compared to $15 \%$ in 2007/2006), the actual increase was $36 \%$ in the reference period while the share of staff costs only reached $39 \%$ in the first four months of 2008 (compared to an average of $32 \%$ in the previous years), which required the need to implement strong measures to comply with the annual budgetary provisions or alternatively significant additional allocations to possible rectification.

$\checkmark$ A matter of concern was the material expenditures (for goods and services) whose nominal dynamics increased to $49 \%$ in $2008 / 2007$ (37\% in real terms), in comparison with $7 \%$ in 2007/2006. The material expenditures are also influenced by inflation (rather rapidly), as the increasing of costs for acquired goods and services determines a significant acceleration of their real growth rate.

$\checkmark$ The expenses for interests increased with $40 \%$ in 2008/2007 (22\% in $2007 / 2006$ and $37 \%$ in 2006/2005) in the context in which the public debt decreased continuously compared with previous years. It is clear that the inflation effect on the market interests' rates has begun to show, both by the adjusting variable interest rates upwards and by the exchange rate depreciation.

$\checkmark$ The capital expenditures registered a sharp nominal increase of $127 \%$ (comparing with $79 \%$ in 4 months $2007 / 4$ months 2006), but the share of annual provisions were further reduced $(20 \%$ in $2008 / 2007,17 \%$ in 2007/2006). Even if the capital expenditures had a rapid dynamics in the first months of 2008, it is to be mentioned that, for the entire year 2007, their growth was only $9 \%$, meaning that a significant deceleration appeared in the second semester of 2008 together with a reassignment to transfers and wages clearly demonstrating the low absorption capacity of the economy in this regard.

The deterioration of international financial conditions determined the worsen of liquidity conditions on the internal market, thus confirming a projection with negative consequences on providing financing for the general consolidated budget deficit, refinancing the debt and covering the temporary resource deficit from the State Treasury general current account for the next period of time (December 2008 - January 2009). Moreover, exactly during this period, characterized by a significant reduction in liquidity, the budget expenditures grossly exceeded the 
Ipate, N., David K.G., Ipate, I., Bogdan, A.T., (2015)

The bioeconomy model in future sustainable development

level of execution of the general consolidated budget revenues, thus accumulating a credit risk of further pressure on funding needs to the State Treasury.

The high budgetary deficit with which Romania began 2009 has limited the budgetary space that could be used in order to mitigate the effects of the financial and economic crisis worldwide.

The additional pressure, accentuated in the last period of 2008, the volatility and lack of trust between the financial market players, together with the worsening of internal and external market liquidity conditions, had an impact upon the budgetary deficit financing and the temporary lack of resources, the State Treasury having to accept, toward the end of 2008, yields much greater than those accepted in the first part of 2008 (a growth of 2.5-3\% comparing to the beginning of 2008) reaching a maximum accepted level of yields of $14.25 \%$ (the Lombard credit facility level).

\section{Financing Policy}

Thus, having as goal the efficient costs minimization, the control and mitigation of risks, the State Treasury did not accept yields higher than this level (the Lombard credit facility level) at the adjudication of government bonds emission, taking into account that in this way the opportunity of arbitration for credit institutions on behalf of operations made by National Bank of Romania and State Treasury could appear. Thus, the State Treasury had to cover the temporary lack of resources, the deficit financing, the public debt refinancing and the refinancing of debits remained uncovered by government bonds - by using available resources in currency transactions or by short time money market transactions.

The evolutions of financial markets, significant changes regarding financing needs, following the exceeding of 2008 budgetary deficit target ${ }^{4}$ with $+2 \%$, the steep economic fallout of GDP from +7.4 to -7.4 , deteriorating conditions (macroeconomic and those of domestic and international financial markets), all have led to the accumulation in the State Treasury of an increased refinancing risk by issuing large volumes of short-term government bonds (approx. 93\% ${ }^{5}$ on short term).

The uncertainties the State Treasury had to work with, based on high volatile market conditions and the lack of trust between investors, made the budget deficit financing strategy for the first part of 2009 to focus mainly on government bonds emissions for internal market (short term emissions, under the market conditions) due to the following factors:

1. The borrowing conditions on international capital markets were extremely disadvantageous, margins over benchmark bonds to which Romanian Eurobonds traded stood at approx. $700 \mathrm{pp}$ (corresponding to yields over $10 \%$ for 10 years maturity); additionally, the lack of investors' appetite for high risk financial assets determined the accentuated increase of costs associated with external loans by charging a high premium to investors in the CDS quotations 
2. Two of State Treasury objectives in public debt administration involved:

- reduction of currency risk afferent to public debt portfolio (still high at that time, considering that over $40 \%$ of portfolio was denominated in other currencies) and

- development of internal government bonds market.

\section{Effects of the Applied Policies and Practice}

The implementation of the financing strategy under the conditions described above, in the context of very high financing pressures, determined the emission of a very large volume of government bonds, of approx. 20 billion lei, in the first 3 months of 2009. It is necessary to mention that the diminishing of credit activities in that period was not due to the emissions of government bonds or to their volume. This phenomenon is due on one hand to decisions from credit institutions - in a context characterized by high incertitude and volatility of credit risk and financing possibilities (banks were seeking to place their resources rather in money market instruments, including government bonds at the expense of lending), and on the other hand (due to lower market demand) to appetite for crediting, especially for economic agents, strongly decreased, while the consumer (construction included) credit has even stagnated.

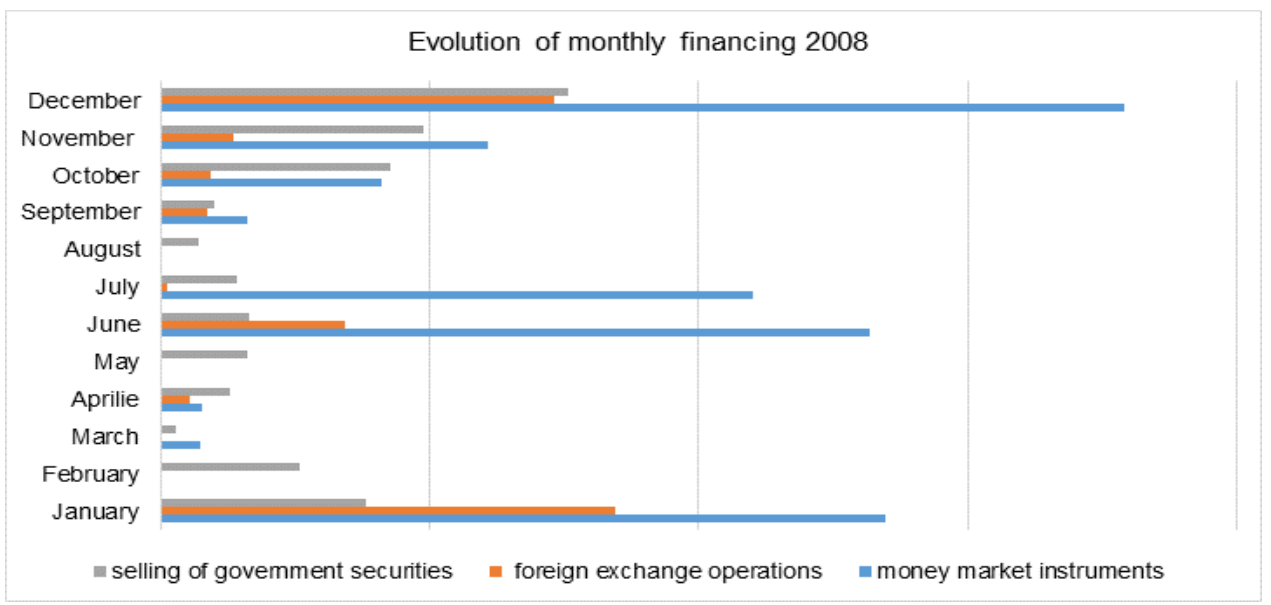

Chart 1 - 2008 evolution of monthly financing Source: Ministry of Public Finance, own processing 
Ipate, N., David K.G., Ipate, I., Bogdan, A.T., (2015)

The bioeconomy model in future sustainable development

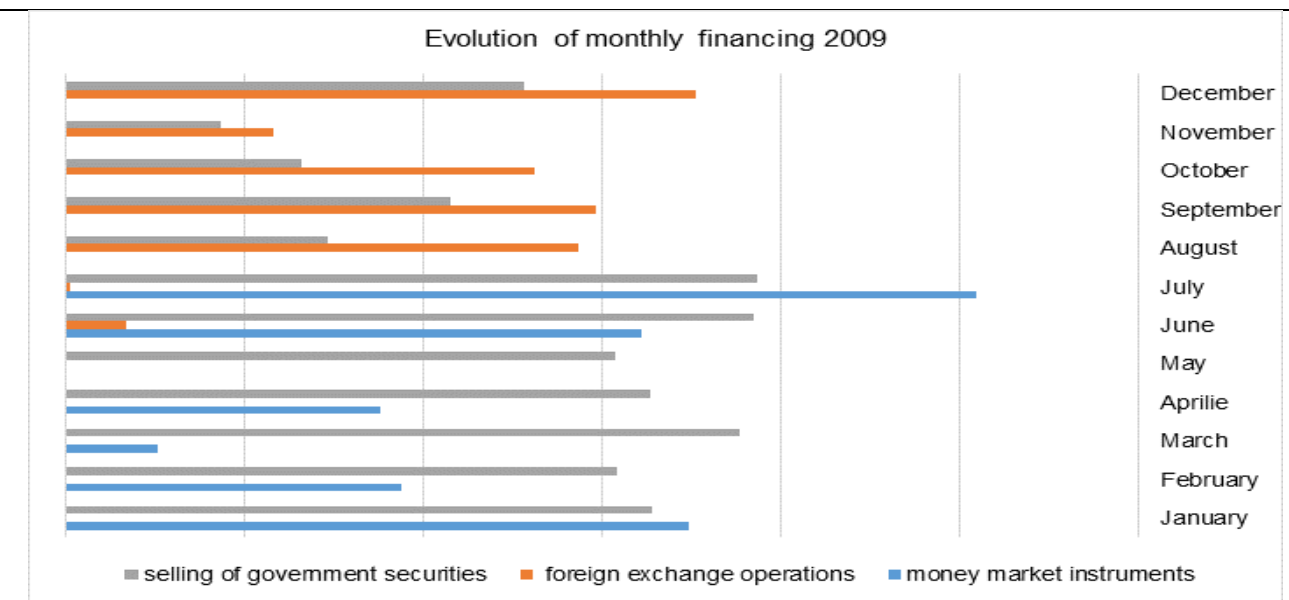

Chart 2 - 2009 evolution of monthly financing

Source: Ministry of Finance, own processing

Thus, in early 2009, financial and credit institutions behavior showed a preference for government bonds, especially short-term, preference justified by the zero risk associated with these instruments compared to corporate loans (which involve a comparatively higher risk, depending on the economic and financial situation of the company).

The funds raised by the State Treasury from the monetary and currency market represented mainly financial resources to undertake its own budgetary expenditure, consisting of public and private sector payments, money which subsequently, depending on the final destination, largely arrived back in the Romanian banking sector - thus achieving a streamlining of payments in connection with other participants without disrupting the smooth operation of the system.

To avoid the appearance of temporary imbalances in general current account of the State Treasury, legal regulations that set a minimum limit to be kept in balance in the conduct of its financial investments have been initiated, in accordance with the current regulations. It also projected the enrolment in the legislative and procedural provisions for clarifying the execution of the treasury bonds guarantees pledged by credit institutions in the placement operations performed by the treasury, and the payment sources of the differences that may arise in case of these guarantees execution.

By issuing government bonds with an average yield of $11.5 \%$, in the corridor of interest charged by the National Bank of Romania to the credit facility (Lombard) of $14.25 \%$, public sector lending using the National Bank of Romania facility is avoided, while creating the necessary the banks collateral to obtain liquidity from banks National Bank of Romania in case of lack of market liquidity. 
However, given the accumulation of an increased refinancing risk by issuing large volumes of short-term government bonds, the State Treasury has considered (in the process of financing) the external borrowing. In this respect, the package for external financing by international financial institutions and the European Commission, both to support the balance of payments and strengthen the foreign exchange reserves (and subsequently to finance the budget deficit) was negotiated. Thus were attained the objectives to minimize the medium and long term costs on new loans and reduce refinancing risk by balancing their maturity, without sacrificing internal loans made through the issuance of bonds on the domestic market, and taking into account targets already mentioned, namely, reducing the currency risk and the development of the government securities market.

In the external financing package, agreed reforms were considered absolute necessary to ensure the financial security of the country, the protection of population economic benefits and to regain credibility with investors.

This necessity is justified in terms of increased refinancing risk accumulation - by issuing large volumes of short-term government securities and taking into account the comparative advantage of costs (loans from international financial institutions can be agreed with very advantageous terms for the Romanian state compared to the costs associated with the issuance of bonds).

The importance of ensuring this financing was reflected in the favorable comments of international rating agencies and in the evolution of the Romanian loan related costs in the international markets, materialized in reduction of trading margins in Romanian Eurobonds and CDS quotations (credit default swaps - the cost of insuring default risk situation) for Romania's sovereign debt by approx. 350-400 bps (3.5-4\%) to levels of approx. 450 bps (4.50\%) and respectively $350-400$ bps $(3.5-4 \%)$.

The country risk assessment at a specific time is based on a detailed analysis of the political and economic situation, the financial sector and the relevant specific indicators, has a direct impact on financing costs associated with sovereign loans issued on international capital markets (since it expresses the ability of a state to pay its debt service obligations).

The only rating agency that has not lowered the sovereign rating below "investment grade" was Moody's, which reconfirmed in the March 20, 2009 the status of "investment grade", highlighting Romania's moderate level of debt. The gradual strengthening of institutions, largely due to the accession to the European Union two years ago was also an important factor. Equally stood the Fitch rating agency's decision of March 25, 2009, considering that the country rate will benefit from the low level of government debt of only $20 \%$ of GDP at the end of 2008, while the refinancing risk was diminished by the fact that in 2009 no outstanding Eurobonds was registered. Fitch also appreciated that the external financing 
Ipate, N., David K.G., Ipate, I., Bogdan, A.T., (2015)

The bioeconomy model in future sustainable development

package represents a support for the country's rating, thereby helping to solve financing needs and balance the economy.

1. The results of the government bonds auctions from early 2009 clearly stands out the investors' appetite towards instruments with short term maturities. This induced the accumulation of an increased refinancing risk - by issuing large volumes of short-term government bonds; the inconvenience was balanced with the implementation of an effective rapid reaction mechanism based on careful observation of real time evolution of State Treasury resources, as well as on a special institutional collaboration between the Romanian National Bank and the State Treasury.

2. The investors' aversion toward risk, coupled with a prudential policy regarding accepted interest rates in the government bonds auctions, have led to changes in favor of short-term securities (of the total government securities approx. 93\% were treasury bills with maturity of 1, 3, 6 months and 1 year, the rest being represented by the benchmark bonds with maturities of 3 and 5 years); also, due to the external financial package, premises were created to achieve the objectives of minimizing the medium and long term costs on new loans with a downward trend.

3. Compared to the yield of government securities issued in December 2008 and early 2009, the yield of government securities issued in July 2009 decreased on average by $3.75 \%$ depending on bonds maturity up to the maximum accepted of $10.5 \%$, following a decreasing trend.

4. By contracting foreign loans, the objectives for cost minimization in the medium and long term on new loans and for refinancing risk reduction by balancing their maturity were achieved - without sacrificing internal loans made by securities issues on the domestic market and taking into account the objectives already mentioned (namely reducing the currency risk and the development of the government securities market).

5. The policy adopted by the State Treasury to ensure the necessary resources has resulted directly in covering the general government deficits, and indirectly in the absorption of excess liquidity in the market which led to:

a. maintaining financial stability and streamlining data flows in the financial market;

b. reducing the pressure on market interest drop at a dangerous pace that would have led to deflationary phenomena.

\section{The Financial Package}

Ensuring the consistent external financing package with a total value of 19.95 billion euros, having an insurance / prudential character towards the potential vulnerabilities that could occur in Romania in the context of global economic and financial crisis, covered both the financing needs of the payment balance (financing package attracted and managed by the National Bank of Romania from the 
Ipate, N., David K.G., Ipate, I., Bogdan, A.T., (2015)

The bioeconomy model in future sustainable development

International Monetary Fund) and an important part of the financing needs of the budget deficit and public debt refinancing, and had a positive impact on investors perception.

Thus, besides the importance of ensuring the external financing, the attached conditions imposed by the International Monetary Fund, European Commission and World Bank have provided the comfort needed for the continuation of structural reforms and measures necessary to mitigate the effects of the financial crisis.

The cost terms for that period were very efficient in terms of costs and in terms of maturity, both for the National Bank of Romania and the Ministry of Public Finance. In that economic context, strongly affected by the economic and financial crisis, funds drawn from the external financing package ensured Romania the possibility of financing the current account deficit and of supporting the payments balance at much lower costs than those that would have been obtained by accessing financial internal and external markets.

Following the signing of a letter of agreement with international lenders and of obtaining the financing package, the return on government securities in December 2008 compared to the yield on government securities issued from February 2009 decreased in average by $2.75 \%$ depending of maturity until $11.5 \%$, and, following the consecutive decisions taken by the National Bank of Romania (from February 2009 to December 2009 monetary policy rate cut to $8 \%$ from $10.25 \%$, the minimum reserve requirement (RMO) in foreign currency to $30 \%$ from $35 \%$ and inflation target this year to $3.5 \%$ ), the yields quoted market has followed a downward trend.

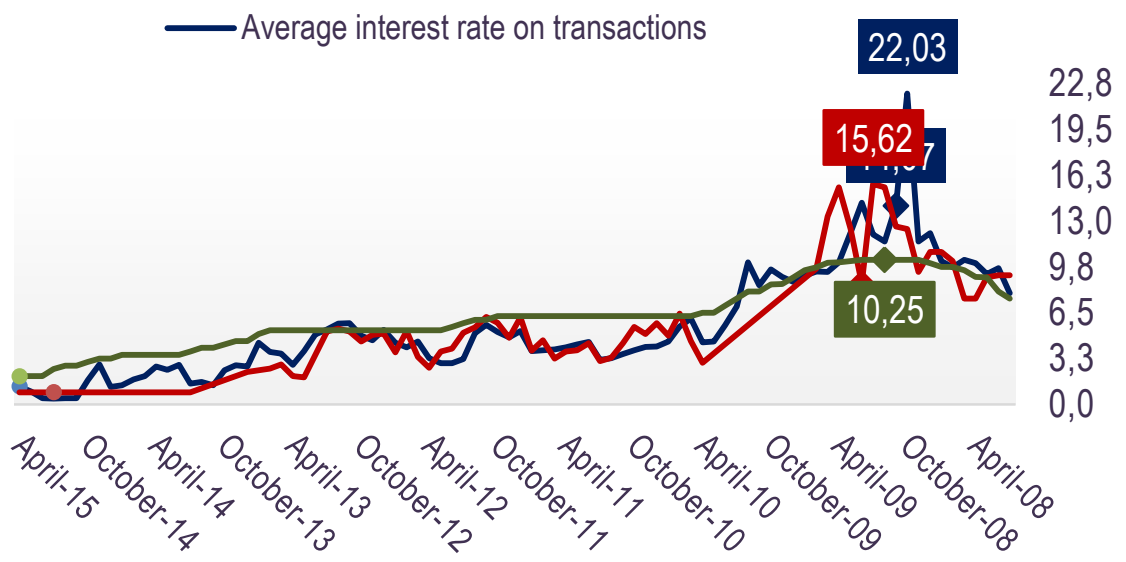

Chart 3 - Evolution of interest in the 2008-2015 period Source: National Bank of Romania, Ministry of Finance, own processing 
Ipate, N., David K.G., Ipate, I., Bogdan, A.T., (2015)

The bioeconomy model in future sustainable development

By contracting the foreign loans, other objectives were also achieved - minimizing the costs related to the new medium and long term loans (for the above mentioned external loans an interest rate of below $4 \%$ was estimated) and reducing of the refinancing risk by balancing the maturities, without sacrificing internal loans made by the issuance of government securities on the domestic market and taking into account the objectives of the government debt management strategy in the medium term to reduce currency risk and development of the government securities market.

\section{Evolution of TSA Cash Flow Projection 2008 - 2010 AVERAGE of month}

$-0-2008-0-2009-0-2010$

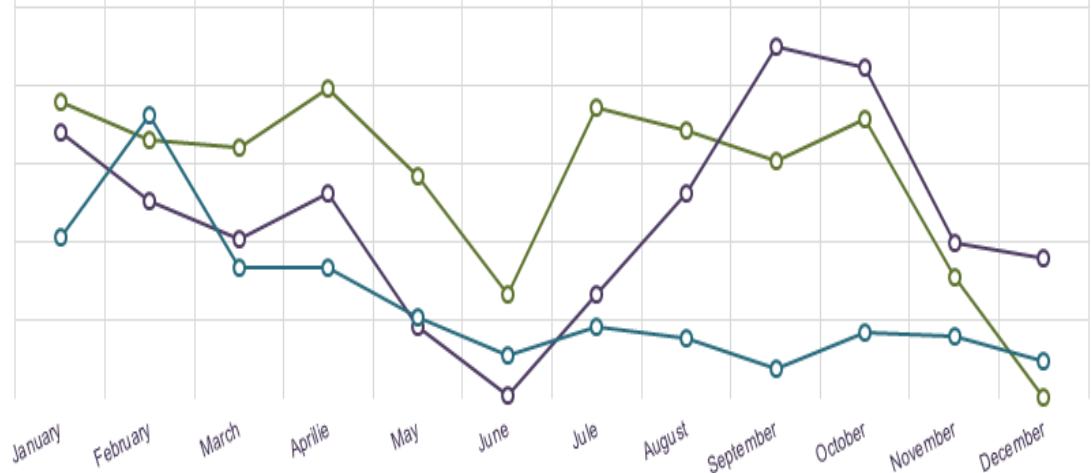

Chart 3 - Evolution Treasury cash during the period from 2008 to 2010, average monthly

Source: National Bank of Romania, Ministry of Finance, own processing

The IMF loan agreement was administered by the National Bank of Romania and Romania and the first Romanian installment was bound for strengthening the country foreign currency reserves. Those funds have played an important role in reducing the mandatory minimum currency reserves in Romanian banks, helping thereby to create an adequate liquidity in the monetary market. Loans agreed with the European Commission, the World Bank and the European Investment Bank were administered by the Ministry of Public Finance and the drawn amounts has fuelled the currency account of the State Treasury and has been used to finance the budget deficit and public debt refinancing.

\section{The response of the financial industry related to the crisis-generated changes and innovations}

\section{Lessons Learned}

Monitoring the performance of the liquidity management instruments in the financial environment requires, besides providing the operational part of the 
management process on short term, respectively managing the State Treasury cash balance, an innovative information system designed to be modular, with specific features and robust procedures, swiftly adapted to new requirements generated by the crisis management process.

Thus, in early 2009, monitoring the behavior of financial and credit institutions established their preference for government bonds, especially short-term (justified by the zero risk associated with these debt instruments and the fact that these tools provide immediate liquidity to credit institutions using the intraday facility) compared to corporate loans, which involve a relatively higher risk of counterparties, depending on the economic and financial situation of the company. With a deep understanding of market mechanisms, thanks to solid but flexible innovation-ready procedures, the State Treasury managed, with relative ease, a fast adaptation to the new conditions, while maintaining low cost for new business connections and intensifying its efforts to continuously improve the management process.

Crises generate and require rapid response intervention, materialized through innovation - since innovation is greatly encouraged by crisis situations to solve either dramatic cost reductions, or help increase high margins revenues, or simultaneously handle both.

The global financial services industry which has seen the crisis evolve in bubbles' 'waves' on the stock market, credit market and derivative instruments, was heavily regulated in recent years at global, regional and national levels, imposing strict prudential measures - for capital adequacy (Basel III), for combating fraud and terrorism financing (AML), for agile monitoring and uniform reporting (e.g. realtime reconciliation, intraday liquidity), for providing customized solutions for each customer challenges, for liberalization of new financial instruments processing infrastructures (PSP), new schemes of cards, transactions processing on specialized verticals (i.e. utilities) etc.

Additional pressures on the financial services industry have emerged also due to launch of revolutionary technologies for distributed recording of transactions in open network like Bitcoin's blockchain (the protocol and general ledger behind Bitcoin crypto-currency), for securing the identity of participants transaction, for Ripple correspondent operations restructuring (open standard TCP/IP-based internet protocol), for routing and optimization of PSPs' payments - to clear and settle transactions in real time through a distributed network and to run fast payments in several currencies in many markets.

The response of banking institutions (the vanguard restructuring) has been a systematic approach in redesigning their own institutions, portfolios and operations; thus, the architectural core of automation systems and objectification process consists of back-office systems able to agilely integrate new types of products and services, ensures a flexible access system to customers and business 
partners, and an intelligent customer behavior analysis system segmented on the main institution targets.

In this context the State Treasury has to keep both its operating and competitiveness safety - so as to be able to implement prompt updates for interoperability with the business environment and citizens, to manage financial resources optimally, and to quickly establish, at low cost, new business connections.

\section{Conclusions}

The central administration at large, and in the particular case the State Treasury, are acting in the best interest of the national economy and are meant to safeguard the compliance to the international commitments the country adhered to.

Consequently, in the hypercompetitive global market, the central administration main obligation is to ensure that these guiding anchors benefit the most effective infrastructures and instruments, aimed to catalyze the economic sustainable growth, while best managing the nation's assets.

We are contemporary to the emerging electronic economy, based on knowledge, pervasive access to information and more and more open achievements sharing. Already now, societies and communities are setting the standard of data sharing, both governmental and business wise, creating this way a strong basis for skilled people to create value and thrive accordingly.

It is the instrumental role of the State Treasury to ensure the timely financing of both the government initiatives and of the priority national projects, while imposing the assets use discipline and their prudential deployment. It is also its responsibility to foresee the global and local exposures, and to contain the risks materialization.

To achieve these minimal obligations, the State Treasury should operate highly adaptable and scalable financial instruments and infrastructure, to enable import of the appropriate foreign innovative solutions but also to encourage own innovation. Next articles in this suite are planned to concentrate on these new instruments and infrastructures that can bring efficiency and streamline to both governmental act and to the business local community, while exporting knowhow and financial stability.

\section{Bibliography:}

1. Ananchotikul, N., Zhang, L. (2014), Portfolio Flows, Global Risk Aversion and Asset Prices in Emerging Markets, IMF Working Paper 14/156;

2. Anderson, Phillip, (2007), New Trends and Challenges in Government Debt Management, 
3. Blommestein, Hans J., and Turner, Philip, 2011, "Interactions between Sovereign Debt Management and Monetary Policy under Fiscal Dominance and Financial Instability," (Social Science Research Network);

4. Brits, H., and C. Winder (2005), Payments Are No Free Lunch, De Nederlandsche Bank, Occasional Studies, Vol. 3/Nr. 2 (preliminary version published as: De Nederlandsche Bank (2004), The Costs of Payments: Survey on the Costs Involved in POS Payment Products, Working Group on Costs of POS Payment Products, March);

5. Cheney, J. (2006), "Supply- and Demand-Side Developments Influencing Growth in the Debit Market," Payment Cards Center Discussion Paper, Federal Reserve Bank of Philadelphia;

6. Campanaro, A. and Vittas, D. (2004) 'Greco-Roman Lessons for Public Debt Management and Debt Market Development', World Bank Policy Research Working Paper 3414.

7. Currie, Elizabeth and Jorge Cardona, (2006) "Management of Contingent Liabilities", in Morgan Stanley Sponsored, "Government Debt Management: New Trends and Challenges", Central Banking Publications, London

8. Chance, D., Grant, K. si Marsland, J., (2010). Risk management, CFA Programm Curriculum, Vol.5, Pearson Custom Publishing, Boston

9. Ebeke C., Lu, Y. (2014), Emerging Market Local Currency Bond Yields and Foreign Holdings in the Post Lehman Period - a Fortune or Misfortune?, IMF Working Paper No 14/29;

10. Hashim, Ali; Allan, Bill. (2001). Treasury Reference Model World Bank Technical Paper no.505 (http://elibrary.worldbank.org/doi/pdf/10.1596/0-8213-4945-7)

11. Jain-Chandra,.S, Unsal, D.F. (2012), The Effectiveness of Monetary Policy Transmission Under Capital Inflows: Evidence from Asia, IMF Working Paper 12/265

12. Jaramillo, L., Weber, A. (2012) Bond Yields in Emerging Economies: It Matters What State You Are In, IMF Working Paper No 12/198;

13. Jula, Dorin, Jula, Nicoleta, (2009) Macroeconomie financiara, Ed. Mustang, Bucuresti,;

14. Tsoukis, Christopher; Agiomirgianakis, M. George; Biswas, Tapan. (2004). Aspects of globalisation: macroeconomic and capital market linkages in the integrated world economy. Norwell, Kluwer Academic Publishers

15. Turner, P. (2014), The global long-term interest rate, financial risks and policy choices in EMEs, BIS Working Papers No 441;

16. Miyajima, K., Mohanty, M.S., Chan, T. (2012), Emerging market local currency bonds: diversification and stability, BIS Working Papers No 391;

17. M.Wielechowsky, (2011) "General Government deficit and public debt in EU member states"; Warsaw University of Life Science SGGW, working paper no. 4;

18. Mu, Y. (2006) 'Government Cash Management: Good Practice \& Capacity - Building Framework', World Bank Financial Sector Discussion Series

19. P. Paun, P, Brezeanu (2013), "Theoretical aspects regarding public expenditure", Annals of University of Petrosani, Economics;

20. Sailendra Pattanayak, Israel Fainboim, (2010), Treasury Single Account: Concept, Design and Implementation Issues, International Monetary Fund, Working Paper; 
Ipate, N., David K.G., Ipate, I., Bogdan, A.T., (2015)

The bioeconomy model in future sustainable development

21. V. Beker, (2014) "On the European debt crisis", University of Belgrano, University of Buenos Aires, Munich Personal repec archive;

22. Wunnicke, Diane B; Wilson, David R. (1992). Corporate financial risk management: Practical techniques of financial engineering. New York: John Wiley \& Sons

23. World Bank, Treasury, http://siteresources.worldbank.org/INTDEBTDEPT/ Resources/468980-1170954447788/3430000-196698402841/20071107_04.pdf

\section{Research article series:}

1. Carmen M. Reinhart and M. Belen Sbrancia, B.M., (2011), The liquidation of government debt, National Bureau of Economic Research, Working Paper Nr.16893

2. G. Beck and V. Wieland , (2008), "Central Bank misperceptions and the role of money in interest rate rules, Research series

3. G. de Walque, O. Pierrard and A. Rouabah, (2008), "Financial (in)stability, supervision and liquidity injections: A dynamic general equilibrium approach", Research series.

4. F. De Graeve, M. Dossche, M. Emiris, H. Sneessens and R. Wouters 2008, "Risk premiums and macroeconomic dynamics in a heterogeneous agent model", Research series,

5. I. Maes, (2009), "On the origins of the BIS macro-prudential approach to financial stability: Alexandre Lamfalussy and financial fragility", Research series

6. K. AssenmacherWesche and S. Gerlach, (2008), "Monetary policy, asset prices and macroeconomic conditions: A panel-VAR study, Research series

7. M. Dombrecht and R. Wouters, (2000), "Model-based inflation forecasts and monetary policy rules", Research Series

\section{Online sources:}

Ministry of Public Finance, www.mfinante.ro

National Institute for Statistics, www.insse.ro

National Bank of Romania, www.bnr.ro

International Monetary Fund, www.imf.org

European Union portal, http://ec.europa.eu/.

\section{Notes:}

${ }^{1}$ Lamfalussy Report for european market regulation of mobile assets, 2001

${ }^{2}$ FMI estimations from World Economic Outlook Prognosis April 2010, http://www.imf.org/external/pubs/ft/weo/2010/01/weodata/index.aspx

${ }^{3}$ Ministry for Public Finance (www.mfinante.ro) own extracting and interpretation

${ }^{4}$ Ministry of Public Finance (www.mfinante.ro) own processing and interpretation

${ }^{5}$ The investor's aversion of risk coupled with the prudential policy regarding interest rates accepted in the auctions of government securities led to changing weights for short-term securities (considering the total of government securities, approx. 93\% were certified treasury with maturities from 1, 3, 6 months and 1 year, the difference being represented by the benchmark bonds with maturities of 3 to 5 years) 